\title{
ANALISIS PENINGKATAN KEMAMPUAN STRATEGI PEMASARAN DENGAN MENGGUNAKAN TEKNOLOGI INFORMASI PADA BISNIS PERHOTELAN DI KOTA BATAM
}

\author{
Daniel Apdianto Herman \\ Sistem Informasi, Universitas Internasional Batam, Indonesia \\ Email: daniel.herman@uib.ac.id \\ DOI: https://doi.org/10.46880/jmika.Vol5No2.pp104-109
}

\begin{abstract}
The development of the hospitality business in Batam is increasingly making competition and competition between hotels tighter. Competition and competition make the management of hotels must have good marketing strategy skills so that they can increase the sales volume and room occupancy rate of their hospitality business. The reason of this observe is to discover how information technology can improve the ability of marketing strategies in terms of sales volume and room occupancy rates in the hospitality business. The sampling method of this research was performed through the usage of purposive sampling with the wide variety of respondents as many as 50 people who were taken intentionally. The conclusion tool used is SWOT analysis to take benefit of possibilities and maximize strengths, lessen weaknesses, and additionally avoid threats. The Strengths-Opportunities (SO) strategy is implemented using brand positioning through the development of hotel websites, maximizing cooperation with travel agents by providing easy booking using online technology applications. In the ST strategy, it is applied by conducting a comparative analysis of room quality and room prices with star-class hotels through information technology, using promotional media supported by technological advances. In the WO strategy by minimizing weaknesses by analyzing cost components, renovating rooms with the help of using information technology. Then the WT strategy that is carried out is to improve the quality of service by using mobile check-in.
\end{abstract}

Keyword: Marketing Strategy, SWOT Analysis, Sales Volume, Room Occupancy.

\begin{abstract}
ABSTRAK
Pembangunan bisnis perhotelan di Batam semakin membuat ketatnya persaingan dan kompetisi di antara hotelhotel. Persaingan dan kompetisi tersebut membuat manajemen dari hotel-hotel harus memiliki kemampuan strategi pemasaran yang baik sehingga dapat meningkatkan volume penjualan dan tingkat hunian kamar dari bisnis perhotelan mereka. Tujuan dari penelitian ini adalah untuk mengetahui bagaimana teknologi informasi dapat meningkatkan kemampuan strategi pemasaran di lihat dari volume penjualan dan tingkat hunian kamar pada bisnis perhotelan. Metode pengambilan sampel penelitian ini dikerjakan dengan memanfaatkan purposive sampling bersama jumlah responden sebanyak 50 orang yang diambil secara sengaja. Alat kesimpulan yang digunakan adalah analisis SWOT untuk memanfaatkan peluang dan memaksimalkan kekuatan, mengurangi kelemahan dan juga menjauhi ancaman. Strategi Strengths-Opportunities (SO) yang diterapkan dengan menggunakan brand positioning melalui pengembangan situs web hotel, memaksimalkan kerjasama dengan travel agent dengan memberikan kemudahan booking menggunakan aplikasi teknologi secara online. Pada strategi ST, diterapkan dengan melakukan analisa perbandingan dari kualitas kamar dan harga kamar dengan hotel sekelas sesuai bintang melalui teknologi informasi, menggunakan media promosi dengan di dukung kemajuan teknologi. Pada strategi WO dengan meminimalkan kelemahan dengan melakukan analisis komponen biaya, melakukan renovasi kamar dengan di tunjang penggunaan teknologi informasi. Kemudian pada strategi WT yang dilakukan adalah melalukan peningkatan kualitas pelayanan dengan menggunakan mobile check-in.
\end{abstract}

Kata Kunci: Strategi Pemasaran, Analisis SWOT, Volume Penjualan, Tingkat Hunian Kamar.

\section{PENDAHULUAN}

Bisnis perhotelan merupakan salah satu faktor industri yang memiliki peranan penting dalam perkembangan pariwisata di Indonesia. Jumlah kunjungan wisatawan baik mancanegara maupun wisatawan dalam negeri yang mengalami peningkatan akan sangat berpengaruh pada perkembangan bisnis perhotelan dikarenakan dengan meningkatnya jumlah kunjungan wisatawan akan meningkatkan pula kebutuhan dari jasa akomodasi khususnya bisnis 
perhotelan sebagai sarana penunjang (Orfila-Sintes \& Mattsson, 2009).

Dengan terjadinya perubahan perekonomian di Indonesia yang semakin meningkat disertai dengan pengembangan baik secara infrastruktur maupun tata letak melalui fasilitas publik untuk kebutuhan masyarakat, yang mana hotel menjadi salah satu didalamnya. Tingkat pertumbuhan hotel terus bertambah jumlahnya setiap tahun di Indonesia. Bidang usaha perhotelan menjadi salah satu jenis industri yang memberikan kontribusi dalam menghasilkan dan menyediakan produk baik berupa barang maupun jasa. Setiap produk atau jasa yang di sediakan hotel baik berwujud maupun tidak berwujud seperti layanan hotel, hiburan di dalam hotel, lingkungan yang asri dan nyaman, bersih, cantik dan indah. Kementrian Pariwisata dan Ekonomi Kreatif mengenai standar usaha hotel, yakni merupakan usaha yang menyediakan akomodasi yakni kamar yang berada di dalam suatu bangunan, dengan di lengkapi juga fasilitas tambahan seperti layanan makanan dan minuman, hiburan di dalam hotel serta fasilitas lainnya untuk mendapatkan keuntungan tambahan bagi usaha hotel tersebut.

Internet sediakalanya saat ini sering dijadikan pusat informasi yang paling utama pada industri kepariwisataan, dimana internet turut merubah business model yang berasal dari faktor pariwisata terlebih di dalam bidang usaha perhotelan dan jasa transportasi. (Noor, Ani; Marceilla; Amalia, 2019) didalam penelitiannya, menyampaikan bahwa perkembangan bisnis secara elektronik dapat mempengaruhi menurunnya konsumen menggunakan agen perjalanan wisata untuk mendapatkan jasa, karena saat ini konsumen dapat dengan mudah menggunakan beragam layanan perusahaan perjalanan wisata online yang dikenal dengan istilah OTA (Online Travel Agent) (Wisata \& Hendriyati, 2019).

Persaingan bisnis dikala ini sudah mendesak para pengelola bisnis (ataupun calon pelaksana bisnis) guna bergerak cepat, kreatif serta antisipatif. Hal ini diakibatkan oleh pergantian mendasar dalam sistem persaingan bisnis yang menggunakan teknologi. Pergantian tersebut meliputi sistem perdagangan, metode bertransaksi, sistem pemasaran ataupun sistem pembayaran (Widiyanto \& Prasilowati, 2015). Paling utama pada industri yang bergerak di bidang pariwisata seperti industri tour and travel, hotel, serta pula maskapai penerbangan sudah memfokuskan pada pengembangan kualitas web selaku langkah inovasi dalam melaksanakan digitalisasi produk (Ongsakul et al., 2020).
Strategi pemasaran adalah pendekatan pokok yang dapat digunakan oleh bidang usaha bisnis di dalam mencapai sasaran yang telah ditetapkan terlebih dahulu sebelumnya, didalamnya dicantumkan keputusan-keputusan pokok perihal target pasar, penempatan produk di area pasar, bauran pemasaran, dan tingkat biaya pemasaran yang dibutuhkan (Nurhayati \& Wulandari, 2017).

Didalam penelitian lainnya, penelitian yang memfokuskan untuk mengetahui bagaimana strategi pemasaran yang tepat dalam meningkatkan tingkat hunian kamar pada Hotel Bali Mandira, Bali. Dengan menggunakan Analisis SWOT, peneliti dapat menyimpulkan strategi pemasaran yang tepat untuk meningkatkan tingkat hunian kamar (Wijaya \& Santoso, 2018).

Penelitian sebelumnya mencoba menjelaskan bahwasanya penggunaan strategi pemasaran digunakan sebagai upaya meningkatkan target penjualan pada bidang usaha perhotelan di Canvinton Hotel yang berada di daerah Yogyakarta. Metode yang digunakan pada penelitian ini adalah metode deskriptif kualitatif, yakni dengan menggunakan analisis SWOT guna memberdayakan peluang yang ada serta memaksimalkan tingkat kekuatan, dan tidak lupa mencoba melakukan pengurangan didalam kelemahan yang di ikuti dengan menghindari ancaman yang bisa terjadi. Strategi S-O, Strategi S-T, Strategi W-O, dan Strategi W-T yang digunakan dan diterapkan guna meningkatkan target penjualan pada Hotel Canvinton yang terletak pada Kota Yogyakarta yakni dengan mencoba memberikan fasilitas tambahan seperti ruang rapat dan tempat bersantai Malioboro Sky, diikuti dengan mencoba mempromosikan produk-produk terbaru makanan dan minuman yang disesuaikan dengan kondisi lingkungan masyarakat sekitarnya, memberikan pelatihan bagi masyarkat sekitar dengan memberikan pelatihan pendidikan pengenal table manner serta kelas memasak, penambahan inovasi produk lainnya yakni acara khusus keluarga, mencoba merambah pasar baru seperti B2B dan B2C, dan tidak lupa mencoba melakukan peningkatan harga yang di ukur secara kompetitif (Atmoko, 2018).

Adapun tujuan dari penelitian ini ialah guna membagikan kontribusi terhadap pengetahuan terpaut peningkatan keahlian strategi pemasaran dengan memakai teknologi informasi di lihat melalui volume penjualan serta tingkatan hunian kamar. 


\section{METODE PENELITIAN}

Penelitian ini hendak melaksanakan analisis terhadap strategi pemasaran memakai teknologi informasi yang dilakukan oleh hotel- hotel di kota Batam dengan memakai analisis SWOT (Sanjaya, Arianty, Suwintari, \& Dewi, 2020). Sumber informasi yang digunakan merupakan kuesioner yang diisi oleh karyawan maupun pihak yang memahami strategi pemasaran hotel- hotel tersebut. Informasi yang diperoleh dari kuesioner dalam wujud bobot serta rating ditabulasikan sehingga diperoleh dasar penentuan strategi pemasaran memakai teknologi data buat tingkatkan volume penjualan serta tingkatan hunian kamar pada hotel hotel di kota Batam.

Penelitian ini memakai judgement sampling yang terhitung dalam purposive sampling dengan memilah anggota sampel berdasarkan keperluan penelitian serta responden yakni orang - orang yang paham benar kondisi hotel yang diteliti baik internal ataupun eksternal. Sampel yang diambil berjumlah 50 orang responden yang meliputi segala staff dari berbagai departemen hotel - hotel di kota Batam.

Adapun kuesioner yang akan dipergunakan memiliki empat bagian yang di bagi menjadi 14 indikator internal dan 9 indikator eksternal. Dua angket menghendaki para responden agar dapat memberikan bobot serta dua angket lainnya meminta semua responden untuk memberikan rating. Analisis SWOT adalah merupakan teknik analisa yang akan di gunakan pada penlitian ini, yaitu suatu teknik analisis yang memiliki kemampuan untuk melakukan identifikasi dalam berbagai faktor secara sistematis guna memberikan formula pada strategi sebuah perusahaan. Teknik Analisis SWOT yang digunakan, memberikan dasar logika yang dapat memaksimalkan kekuatan (strengths) dan peluang (opportunities), akan tetapi dalam waktu yang sama bisa dipergunakan untuk meminimalisir kelemahan (weaknesses) dan ancaman (threats).

Didalam penelitian ini, peneliti tidak menggunakan formula atau rumus. Namun peneliti menggunakan rata-rata jawaban responden. pertanyaan yg diberikan kepada responden terkait bobot dan rating, kemudian dari rata-rata jawaban 54 responden. responden diminta memberi peringkat pada setiap pertanyaan, baik untuk BOBOT dan RATING. kemudian dirata-rata response dari mereka

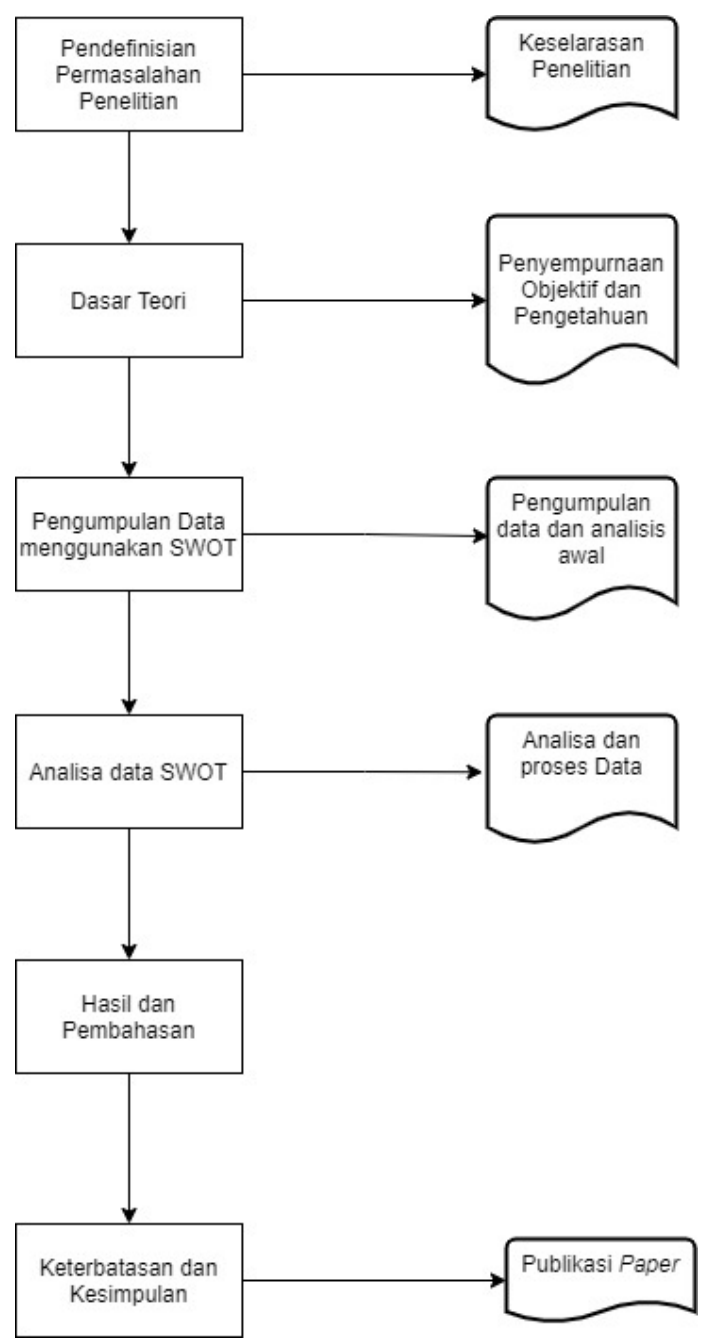

Gambar 1. Flow Diagram Penelitian

Didalam penggunaannya di lingkungan internal, memberikan uraian mengenai kemampuan yang dapat ditonjolkan oleh perusahaan atau bisa di istilahkan kekuatan dari perusahan tersebut dan titik lemah yang ada di dalam perusahaan tersebut. Jika nilai yang didapatkan merupakan hasil yang baik dan sangat baik, maka akan di identifikasikan dengan kekuatan, namun jika hasil yang di dapat kurang baik dan sangat kurang baik, maka akan di identifikasikan dengan kelemahan.

Didalam penggunaanya di lingkungan eksternal, memberikan uraian mengenai peluang dan ancaman. Jika nilai yang didapatkan merupakan hasil yang di katakan baik dan sangat baik, makan akan di identifikasikan sebagai suatu peluang bagi perusahaan tersebut. Namun, jika nilai yang didapatkan merupakan hasil yang di katakana kurang baik atau sangat kurang baik, maka akan di identifikasikan menjadi sebuah ancaman bagi perusahaan.

Analisis SWOT merupakan teknik yang sering dikenal dengan definisi sebagai berikut "Identifikasi beragam faktor secara sistematis dalam hal guna 
merumuskan strategi pada sebuah perusahaan (Rangkuti Freddy, 2016). Teknik pada Analisis ini dilandasi oleh logika yang dapat memberikan kemampuan maksimal pada kekuatan (strengths) dan peluang (opportunities), tapi secara bersamaan bisa memberikan kemampuan untuk meminimalisir kelemahan (weaknesses) dan ancaman (threats)". Setelah mendapatkan hasil berikutnya adalah penulisan laporan dan proses diseminasi hasil penelitian dalam bentuk publikasi jurnal dan konferensi.

\section{HASIL DAN PEMBAHASAN}

Berdasarkan hasil kajian literatur dan diskusi dengan beberapa ahli industri perhotelan di Batam, diidentifikasi 18 faktor internal dan 14 faktor eksternal.

\section{Faktor Internal}

Berikut ini merupakan faktor-faktor internal:

1. Kelengkapan fasilitas dalam kamar hotel

2. Kelengkapan fasilitas hotel

3. Fasilitas bermain untuk anak dan keluarga

4. Kebersihan kamar hotel

5. Kebersihan hotel

6. Keterjangkauan lokasi hotel

7. Kedekatan hotel dengan daerah wisata dan fasilitas umum

8. Penampilan staff hotel

9. Keramahan staff hotel

10. Kecepatan layanan hotel

11. Website hotel yang selalu update informasi

12. Harga yang kompetitif

13. Adanya sistem informasi manajemen hotel

14. Motivasi pekerja

15. Komitmen pemilik hotel untuk kemajuan hotel

16. Kemampuan keuangan hotel untuk operasional

17. Usia bangunan hotel

18. Kualitas makanan dan minuman hotel

\section{Faktor Eksternal}

Berikut ini merupakan faktor-faktor eksternal:

1. Penggunaan smartphone yang semakin berkembang

2. Data internet yang terjangkau

3. Situasi pandemik COVID-19

4. Persaingan industri hotel

5. Kebijakan TCA (Travel Corridor Arrangement) untuk wisatawan asing

6. Kegiatan-kegiatan kebudayaan dan pariwisata di kota Batam

7. Berkembangnya alternatif penginapan selain hotel

8. Banyaknya situs pencarian hotel

9. Berkembangnya penggunaan sosial media untuk mereview produk dan layanan
10. Kebijakan pajak hotel

11. Lokasi strategis kota Batam

Setelah mengidentifikasi faktor internal dan faktor eksternal, maka dilakukan penyebaran kuesioner online kepada para pekerja di sektor perhotelan Batam. Sebanyak 54 responden telah mengisi kuesioner dengan lengkap dan benar. Hasil rekapitulasi data dapat dilihat pada laporan penelitian ini.

\section{Profil Responden}

Profil responden berdasarkan data demografinya antara lain: jenis kelamin, pendidikan, divisi/badian, dan lama bekerja di industri hotel ditunjukkan pada gambar di bawah ini.

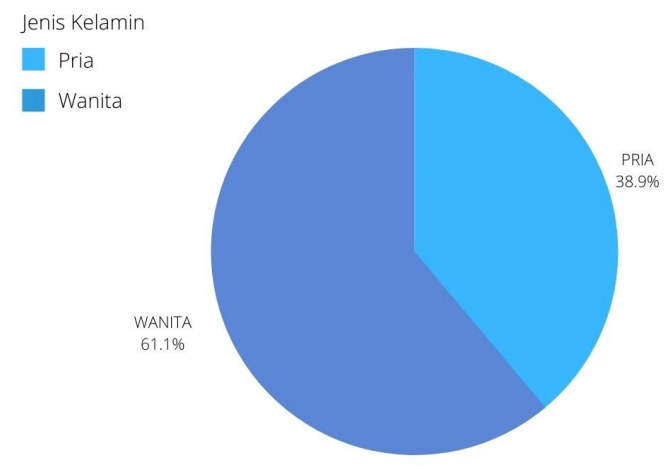

Gambar 2. Profil Responden di Batam

Berdasarkan gambar di atas dapat dilihat bahwa sebagian besar responden berjenis kelamin wanita (33 orang/61,11\%), sedangkan responden pria berjumlah 21 orang $(38,89 \%)$.

\section{Seleksi Faktor Internal dan Faktor Eksternal}

Data rating faktor internal dan eksternal didapatkan dari kuesioner yang disebarkan kepada staff dan manager IT hotel di kota batam. Penghitungan bobot didapatkan dari rata-rata jawaban responden. Hasil bobot faktor internal setelah diurutkan

Tabel 1. Bobot Faktor Internal

\begin{tabular}{|l|l|l|}
\hline Faktor & Bobot & Urutan \\
\hline Kebersihan hotel & 3,78 & 1 \\
\hline $\begin{array}{l}\text { Kualitas makanan dan minuman } \\
\text { hotel }\end{array}$ & 3,76 & 2 \\
\hline Kebersihan kamar hotel & 3,74 & 3 \\
\hline Kelengkapan fasilitas hotel & 3,72 & 4 \\
\hline Keramahan staff hotel & 3,72 & 5 \\
\hline Kecepatan layanan hotel & 3,70 & 6 \\
\hline $\begin{array}{l}\text { Website hotel yang selalu update } \\
\text { informasi }\end{array}$ & 3,70 & 7 \\
\hline $\begin{array}{l}\text { Kemampuan keuangan hotel } \\
\text { untuk operasional }\end{array}$ & 3,67 & 8 \\
\hline
\end{tabular}




\begin{tabular}{|l|l|l|}
\hline $\begin{array}{l}\text { Kelengkapan fasilitas dalam } \\
\text { kamar hotel }\end{array}$ & 3,67 & 9 \\
\hline $\begin{array}{l}\text { Komitmen pemilik hotel untuk } \\
\text { kemajuan hotel }\end{array}$ & 3,65 & 10 \\
\hline Motivasi staff hotel & 3,65 & 11 \\
\hline Penampilan staff hotel & 3,61 & 12 \\
\hline Harga yang kompetitif & 3,59 & 13 \\
\hline $\begin{array}{l}\text { Adanya sistem informasi } \\
\text { manajemen hotel }\end{array}$ & 3,52 & 14 \\
\hline Keterjangkauan lokasi hotel & 3,50 & 15 \\
\hline $\begin{array}{l}\text { Kedekatan hotel dengan daerah } \\
\text { wisata dan fasilitas umum }\end{array}$ & 3,46 & 16 \\
\hline Usia bangunan hotel & 3,41 & 17 \\
\hline $\begin{array}{l}\text { Fasilitas bermain untuk anak dan } \\
\text { keluarga }\end{array}$ & 3,31 & 18 \\
\hline
\end{tabular}

Dari proses wawancara lebih lanjut dengan beberapa orang ahli perhotelan, akhirnya disepakati 14 faktor internal saja yang relevan bagi industri perhotelan batam, yang dipilih berdasarkan urutan bobotnya. Oleh karena itu, faktor internal: Keterjangkauan lokasi hotel, Kedekatan hotel dengan daerah wisata dan fasilitas umum, usia bangunan hotel, dan fasilitas bermain untuk anak dan keluarga akan dibuang dan tidak dimasukkan dalam analisis SWOT.

Hasil bobot faktor eksternal setelah diurutkan ditampilkan pada tabel 2 berikut.

Tabel 2. Bobot Faktor Eksternal

\begin{tabular}{|l|l|l|}
\hline Faktor & Bobot & Urutan \\
\hline $\begin{array}{l}\text { Penggunaan smartphone yang } \\
\text { semakin berkembang }\end{array}$ & 3,70 & 1 \\
\hline Data internet yang terjangkau & 3,69 & 2 \\
\hline Lokasi strategis kota Batam & 3,65 & 3 \\
\hline $\begin{array}{l}\text { Berkembangnya penggunaan } \\
\text { sosial media untuk mereview } \\
\text { produk dan layanan }\end{array}$ & 3,63 & 4 \\
\hline Banyaknya situs pencarian hotel & 3,57 & 5 \\
\hline Persaingan industri hotel & 3,43 & 6 \\
\hline Situasi pandemik COVID-19 & 3,41 & 7 \\
\hline $\begin{array}{l}\text { Kegiatan-kegiatan kebudayaan } \\
\text { dan pariwisata di kota Batam }\end{array}$ & 3,37 & 8 \\
\hline Kebijakan pajak hotel alternatif & 3,33 & 11 \\
\hline $\begin{array}{l}\text { Kebijakan TCA Travel Corridor } \\
\text { Arrangement) untuk wisatawan } \\
\text { asing }\end{array}$ & 3,33 & 10 \\
\hline $\begin{array}{l}\text { Berkembangnya } \\
\text { penginapan selain hotel }\end{array}$ & 9 \\
\hline
\end{tabular}

Adapun wawancara yang dilakukan lebih lanjut dengan beberapa orang ahli perhotelan, akhirnya disepakati 9 faktor eksternal saja yang relevan bagi industri perhotelan batam, yang dipilih berdasarkan urutan bobotnya. Oleh karena itu, faktor eksternal:
Kebijakan TCA (Travel Corridor Arrangement) untuk wisatawan asing dan Berkembangnya alternatif penginapan selain hotel akan dibuang dan tidak dimasukkan dalam analisis SWOT.

Setelah mendapatkan 14 faktor internal dan 9 faktor internal, maka dilakukan pembagian faktor internal menjadi kekuatan dan kelemahan yang dilakukan dengan melihat rating/penilaiannya (kinerja hotel terhadap setiap faktor internal). Demikian juga dilakukan pembagian faktor eksternal menjadi peluang dan ancaman. Tabel bobot dan rating dari faktor internal (kekuatan dan kelemahan) dan faktor eksternal (peluang dan ancaman) ditunjukkan pada tabel di bawah ini.

\begin{tabular}{|c|c|c|c|}
\hline $\begin{array}{l}\text { Faktor } \\
\text { Internal }\end{array}$ & Indikator & Bobot & Rating \\
\hline \multirow[t]{9}{*}{ Kekuatan } & $\begin{array}{l}\text { Kualitas makanan } \\
\text { dan minuman hotel }\end{array}$ & 3,76 & 4,74 \\
\hline & $\begin{array}{l}\text { Kebersihan kamar } \\
\text { hotel }\end{array}$ & 3,74 & 4,78 \\
\hline & $\begin{array}{l}\text { Keramahan staff } \\
\text { hotel }\end{array}$ & 3,72 & 4,96 \\
\hline & $\begin{array}{l}\text { Kecepatan layanan } \\
\text { hotel }\end{array}$ & 3,70 & 4,76 \\
\hline & $\begin{array}{l}\text { Website hotel yang } \\
\text { selalu update } \\
\text { informasi }\end{array}$ & 3,70 & 4,85 \\
\hline & $\begin{array}{l}\text { Kelengkapan } \\
\text { fasilitas dalam } \\
\text { kamar hotel }\end{array}$ & 3,67 & 4,74 \\
\hline & $\begin{array}{l}\text { Komitmen pemilik } \\
\text { hotel untuk } \\
\text { kemajuan hotel }\end{array}$ & 3,65 & 5,02 \\
\hline & $\begin{array}{l}\text { Penampilan staff } \\
\text { hotel }\end{array}$ & 3,61 & 4,91 \\
\hline & $\begin{array}{l}\text { Adanya sistem } \\
\text { informasi } \\
\text { manajemen hotel }\end{array}$ & 3,52 & 4,87 \\
\hline \multirow[t]{5}{*}{ Kelemahan } & Motivasi staff hotel & 3,65 & 4,69 \\
\hline & $\begin{array}{l}\text { Harga yang } \\
\text { kompetitif }\end{array}$ & 3,59 & 4,72 \\
\hline & Kebersihan hotel & 3,78 & 4,72 \\
\hline & $\begin{array}{l}\text { Kelengkapan } \\
\text { fasilitas hotel }\end{array}$ & 3,72 & 4,65 \\
\hline & $\begin{array}{l}\text { Kemampuan } \\
\text { keuangan hotel } \\
\text { untuk operasional }\end{array}$ & 3,67 & 4,67 \\
\hline \multirow[t]{4}{*}{ Peluang } & $\begin{array}{l}\text { Penggunaan } \\
\text { smartphone yang } \\
\text { semakin } \\
\text { berkembang }\end{array}$ & 3,70 & 5,00 \\
\hline & $\begin{array}{l}\text { Data internet yang } \\
\text { terjangkau }\end{array}$ & 3,69 & 5,06 \\
\hline & $\begin{array}{l}\text { Lokasi strategis } \\
\text { kota Batam }\end{array}$ & 3,65 & 4,85 \\
\hline & $\begin{array}{l}\text { Berkembangnya } \\
\text { penggunaan sosial } \\
\text { media untuk }\end{array}$ & 3,63 & 4,83 \\
\hline
\end{tabular}




\begin{tabular}{|l|l|l|l|}
\hline \multirow{7}{*}{} & $\begin{array}{l}\text { mereview produk } \\
\text { dan layanan }\end{array}$ & & \\
\cline { 2 - 4 } & $\begin{array}{l}\text { Kegiatan-kegiatan } \\
\text { kebudayaan dan } \\
\text { pariwisata di kota } \\
\text { Batam }\end{array}$ & 3,37 & 4,00 \\
\hline Ancaman & $\begin{array}{l}\text { Banyaknya situs } \\
\text { pencarian hotel }\end{array}$ & 3,57 & 4,65 \\
\cline { 2 - 4 } & $\begin{array}{l}\text { Persaingan industri } \\
\text { hotel }\end{array}$ & 3,43 & 3,96 \\
\cline { 2 - 4 } & $\begin{array}{l}\text { Situasi pandemik } \\
\text { COVID-19 }\end{array}$ & 3,41 & 3,52 \\
\cline { 2 - 4 } & $\begin{array}{l}\text { Kebijakan pajak } \\
\text { hotel }\end{array}$ & 3,35 & 4,41 \\
\hline
\end{tabular}

\section{KESIMPULAN}

Dalam penelitian yang telah peneliti lakukan yang bertujuan untuk memberikan kontribusi terhadap peningkatan kemampuan strategi pemasaran dengan menggunakan teknologi informasi menunjukkan hasil yang cukup baik. Dalam beberapa aspek terlihat ada yang menunjukkan tidak terlalu signifikan, namun respon terhadap penggunaan teknologi informasi sebagai alat bantu untuk peningkatan kemampuan strategi pemasaran mendapatkan respon yang positif yang berjalan lurus dengan penelitian sebelumnya. Perspektif responden terhadap teknologi informasi mampu meningkatkan kemampuan strategi pemasaran pada bisnis perhotelan. Secara keseluruhan masih mendapatkan respon yang cukup positif terkait pengaruh teknologi informasi pada bisnis perhotelan, namun untuk mengetahui seberapa jauh teknologi informasi pada peningkatan bisnis perhotelan msaih diperlukan penelitian lebih lanjut.

\section{DAFTAR PUSTAKA}

Atmoko, T. P. H. (2018). Strategi Pemasaran Untuk Meningkatkan Volume Penjualan Di Cavinton Hotel Yogyakarta. Journal of Indonesian Tourism, Hospitality and Recreation, 1(2), 8396. https://doi.org/10.17509/jithor.v1i2.13769

Noor, Ani; Marceilla; Amalia, S. (2019). AN ANALYSIS OF E-BUSINESS PROCESS AT THE TOUR AND TRAVEL COMPANIES IN BANDUNG. Tourism Scientific Journal, 4(2), 126-148.

Nurhayati, R., \& Wulandari, A. (2017). Penerapan Strategi Pemasaran Pada Kamojang Green Hotel \& Resort Garut Pada Tahun 2017. EProceedings of Applied Science, 3(2), 558-563.

Ongsakul, V., Ali, F., Wu, C., Duan, Y., Cobanoglu, C., \& Ryu, K. (2020). Hotel website quality, performance, telepresence and behavioral intentions. Tourism Review, 76(3), 681-700. https://doi.org/10.1108/TR-02-2019-0039

Orfila-Sintes, F., \& Mattsson, J. (2009). Innovation
Behavior In The Hotel Industry. Omega, 37(2), 380-394.

https://doi.org/10.1016/j.omega.2007.04.002

Rangkuti Freddy. (2016). ANALISIS SWOT: Teknik

Membedah Kasus Bisnis Cara Perhitungan

Bobot, Rating, dan OCAI. PT. Gramedia. Jakarta.

Sanjaya, I. W. K., Arianty, A. A. A. S., Suwintari, I. G. A. E., \& Dewi, I. G. A. M. (2020). A Swot Analysis of Online Room Reservation in Hotel Sectors. (A Case Study in Bali Hsovereign Hotel). Journal of Business on Hospitality and Tourism, 6(1), 113. https://doi.org/10.22334/jbhost.v6i1.202

Widiyanto, I., \& Prasilowati, S. L. (2015). Perilaku Pembelian Melalui Internet. Jurnal Manajemen Dan Kewirausahaan, 17(1), 109-112. https://doi.org/10.9744/jmk.17.2.109

Wijaya, C. P., \& Santoso, T. P. B. (2018). Strategi Pemasaran Dalam Meningkatkan Tingkat Hunian Kamar Pada Hotel Bali Mandira Legian - Bali. Jurnal Ekonomi Dan Pariwisata, 13(1), 42-53.

Wisata, J. M., \& Hendriyati, L. (2019). Pengaruh Online Travel Agent Terhadap Pemesanan Kamar Di Hotel Mutiara Malioboro Yogyakarta. 17(November), 1-10. https://doi.org/10.31227/osf.io/e3st8 